Department of Veterinary Anatomy (Prof. M. YASUDA), Faculty of Agriculture, Nagoya University, Nagoya, Japan

\title{
Fine Structure of the Pancreatic Islets in Domestic Fowl with Special Reference to the Cell Type and Secretion
}

\author{
Tohru Watanabe, Young Ki Paik* and Mikio Yasuda
}

Received June 9, 1975

\begin{abstract}
Summary. The pancreatic islets of domestic fowl were investigated by electron microscope. The following results were obtained.

1. The $A$ islet is composed of a great many A cells and a few $D$ cells. It also contained only a few $B$ cells which are situated mainly along capillaries.

2. On the contrary, the $B$ islet is composed of a great many $B$ cells and a few D cells. It also contained only a few $A$ cells in its periphery.

3. Immature secretory granules within the Golgi complex are almost the same in size, shape and density among the three types of islet cells. Since there are quite distinct differences in these properties of mature secretory granules in the cytoplasm among the three types of islet cells, there may be a difference in the mode of maturation process among the three.
\end{abstract}

4. These granules are released from the three types of islet cells through a mechanism termed as emiocytosis.

Although numerous reports have been made on the fine structure of the pancreatic islets of various species of vertebrates, only a few papers have been published on the pancreatic islets of birds, especially domestic fowl (Machino et al., $1966 \mathrm{a}, \mathrm{b}$; Przybylski, 1967; Machino and Sakuma, 1968; Machino, 1970; Peter, 1970; Mikami and Mutoh, 1971; Benzo and Green, 1974). Since two types of pancreatic islets were distinguished by the light microscope, it has been possible to separate A islets, which consist mainly of A and D cells, from B islets, which consist mainly of B and D cells, by the electron microscope (Miкамі and Мuтон, 1971).

BRAUn-BlanQUET (1969) reported, however, that the clear islet was composed of B cells surrounded by a mantle of A cells in the duck. KoBAy ashi and Fujit A (1969) pointed out that there frequently occurred islets of a "mixed type" which contained all three cell types mingled together. These previous studies have not coincided in results with one another as yet. The present study was started with the first aim of deciding cell types forming the two types of islets in domestic fowl.

It was already reported that the secretory mode of the A and D cells was emiocytosis in normal domestic fowls (Machino et al., $1966 \mathrm{a}, \mathrm{b}$ ). There had been, however, no firm evidence given to support the occurrence of emiocytosis in the $B$ cells of the pancreatic islet of domestic fowl, until recently BENZo and GREEN (1974) indicated for the first time that the B granules in the embryonic chick were released by emiocytosis.

There were some different opinions as to synthesis, storage and release of secretory granules in the islet cells. The second aim of this paper is to clarify the maturation process and the releasing process of secretory granules in the islet cells of the adult domestic fowl.

* The second author is from the Department of Veterinary Anatomy, Agricultural College, Chonpuk University, Chonju, Korea. 


\section{Materials and Methods}

Seven domestic fowls of either sex (Brown Leghorn), 1 day to 8 months old, were used in this investigation.

For immersion fixation, the abdomen was cut open widely in chicks just after hatching and in adult fowls. Fixative was poured on the tail of the pancreas. A small tissue block was excised from this area and cut into fine pieces in the fixative for fixation. The fixative used was $5 \%$ glutaraldehyde buffered at $\mathrm{pH} 7.4$ with an $0.2 \mathrm{M}$ cacodylate buffer for 2 hrs (SABATINI et al., 1963) and rinsed first with $7.3 \%$ sucrose in the same cacodylate buffer and followed by $1 \%$ osmium tetroxide in phosphate buffer (MILLONIG, 1962).

For perfusion fixation, adult fowls were anesthetized with sodium pentobarbiturate. In them, the abdomen was cut open between the last two ribs to dissect the celiac artery, into which a vinyl cannula was inserted and tied in place. The cannula was connected with an irrigator filled with a fixative (consisting of $2.5 \%$ glutaraldehyde and $4 \%$ paraformaldehyde in $0.2 \mathrm{M}$ cacodylate buffer at $\mathrm{pH} 7.3$ containing $0.002 \%$ calcium chloride) (KARNOvsky, 1956). Perfusion was maintained for $10-15 \mathrm{~min}$ at a pressure of $100-120 \mathrm{~cm} \mathrm{H}_{2} \mathrm{O}$. Tissue blocks were cut from the tail of the pancreas and fixed in the same fresh fixative for about $2 \mathrm{hrs}$. They were rinsed first with $7.3 \%$ sucrose in the same cacodylate buffer and followed by $1 \%$ osmium tetroxide in phosphate buffer (Millonig, 1962).

All the fixed blocks were dehydrated with graded concentrations of alcohol and embedded in Epon 812 (LufT, 1962). Thin sections were cut from them on a PoterBlum MT-1 microtome, stained with saturated uranyl acetate and lead, and observed under a JEM T7-S electron microscope.

\section{Results}

The two types of islets were easily identified in the domestic fowl pancreas. A islets were always restricted within the tail of the pancreas, especially the splenic lobe, and larger than B islets which were widely distributed all over the pancreas. The A islet was composed of abundant A cells and a few D cells, and the B islet of abundant B cells a few D cells, as shown in previous literature.

Detailed observation of the sections, however, revealed that the majority of A islets contained only a few B cells in addition to A and D cells. Most B cells were situated separately or in clumps along capillaries in the A islet (Fig. 1). Therefore, it seems that the A islet may belong to the "mixed type" in which all three cell types mingled with one another.

The A cells were variable in shape, often columnar, and exhibited a palisade arrangement around the capillary. They were characterized by the presence of dense, spherical granules in the cytoplasm (Fig. 1, 2, 3). The granules were $410 \mathrm{~m} \mu$ (ranging from 310 to $570 \mathrm{~m} \mu$ ) in diameter and uniform in shape and density at a lowpower magnification (Fig. 1). At a high-power magnification they appeared quite variable in density with irregular or serrated edges (Fig. 2, 3), and were separated by a narrow halo zone from the limiting membrane. They often showed an inner glomerular structure (Fig. 3). The nucleus was round or ovoid and often exhibited a deep indentation (Fig. 1, arrows), frequently containing some granules (Fig. 1, inset). 


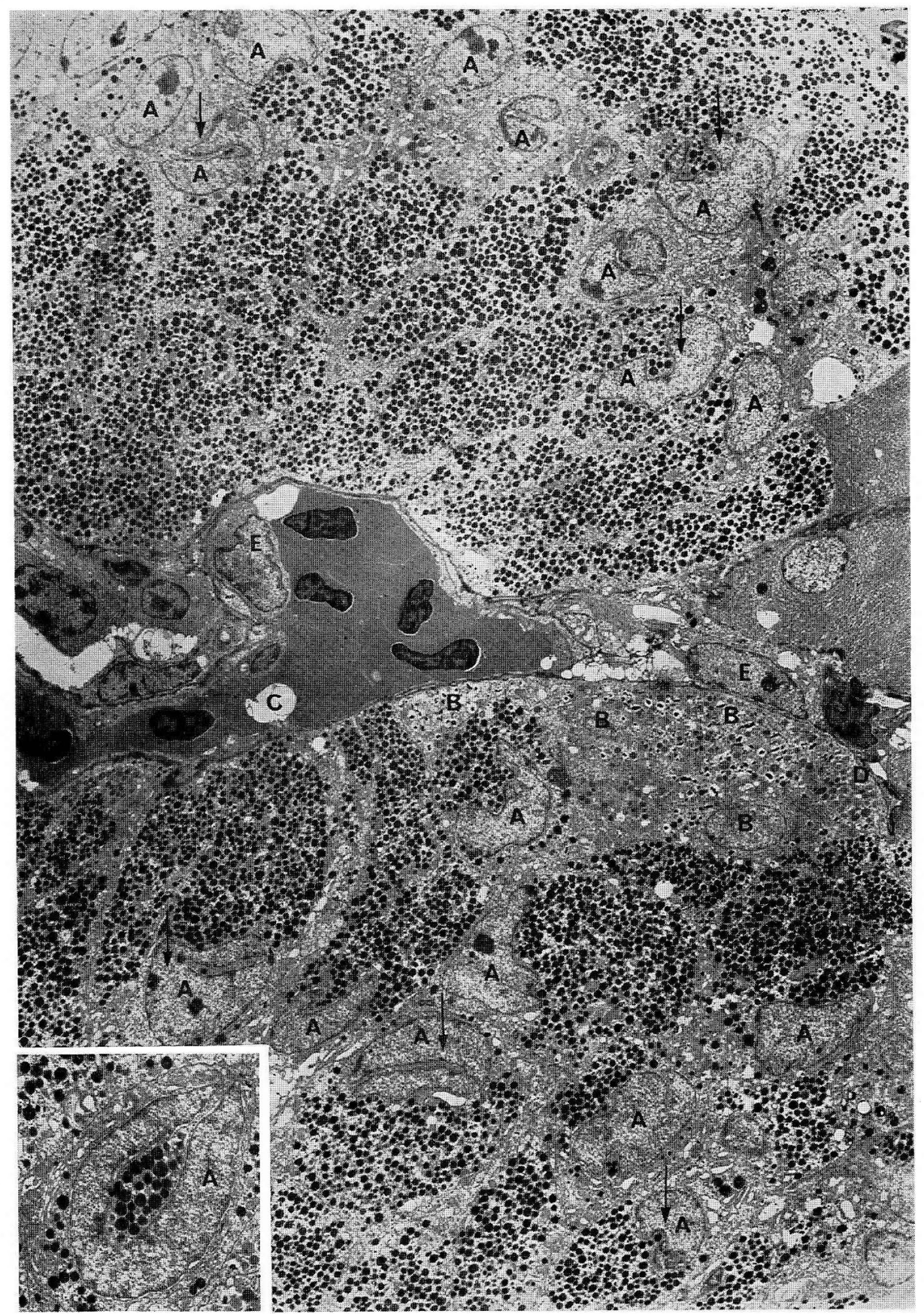

Fig. 1. An electron micrograph of the $A$ islet. Note the presence of some $B$ cells $(B)$ in the $A$ islet which is composed of $\mathrm{A}(A)$ and $\mathrm{D}$ cells $(D)$. The $\mathrm{B}$ cells are situated mainly along the capillary $(C)$ in the $\mathrm{A}$ islet. In some $\mathrm{A}$ cells the nucleus has a deep indentation (arrows), containing some A granules (inset). $E$ endothelium. $\times 2,600$ 


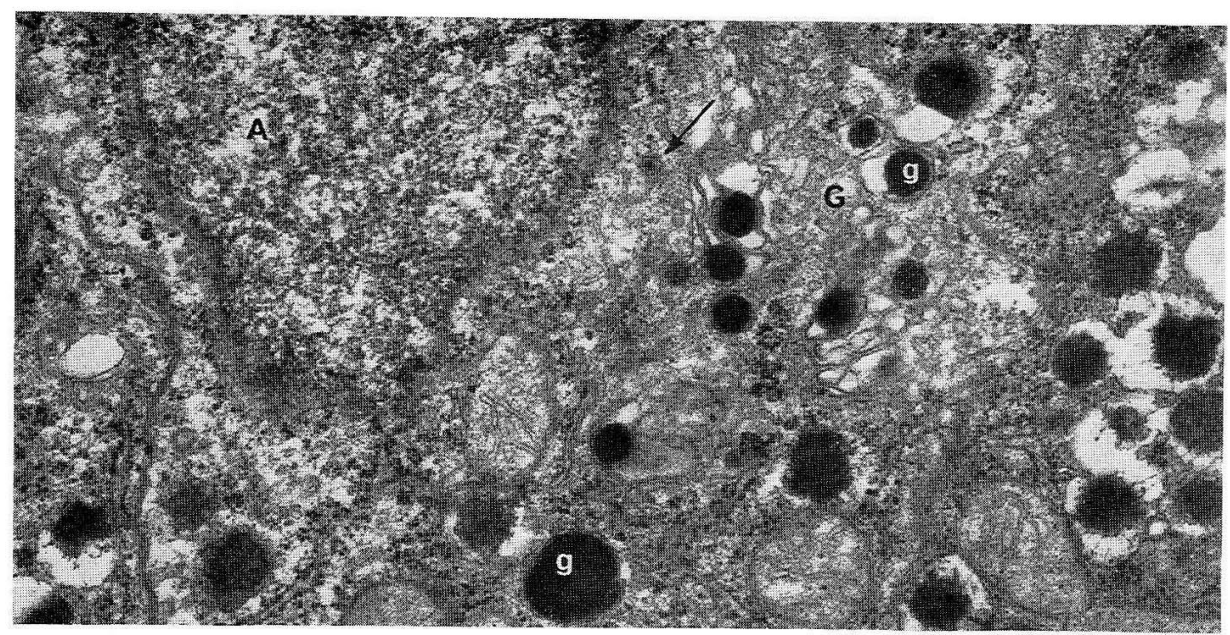

Fig. 2. Golgi complex $(G)$ of the A cell $(A)$. The appearance of amorphous material in a small Golgi vesicle suggests the formation of granules (arrow). Immature granules $(g)$ within the Golgi area show almost the same appearance as those of B and D cells. Compare with Figures 6 and 8 . $\times 20,000$

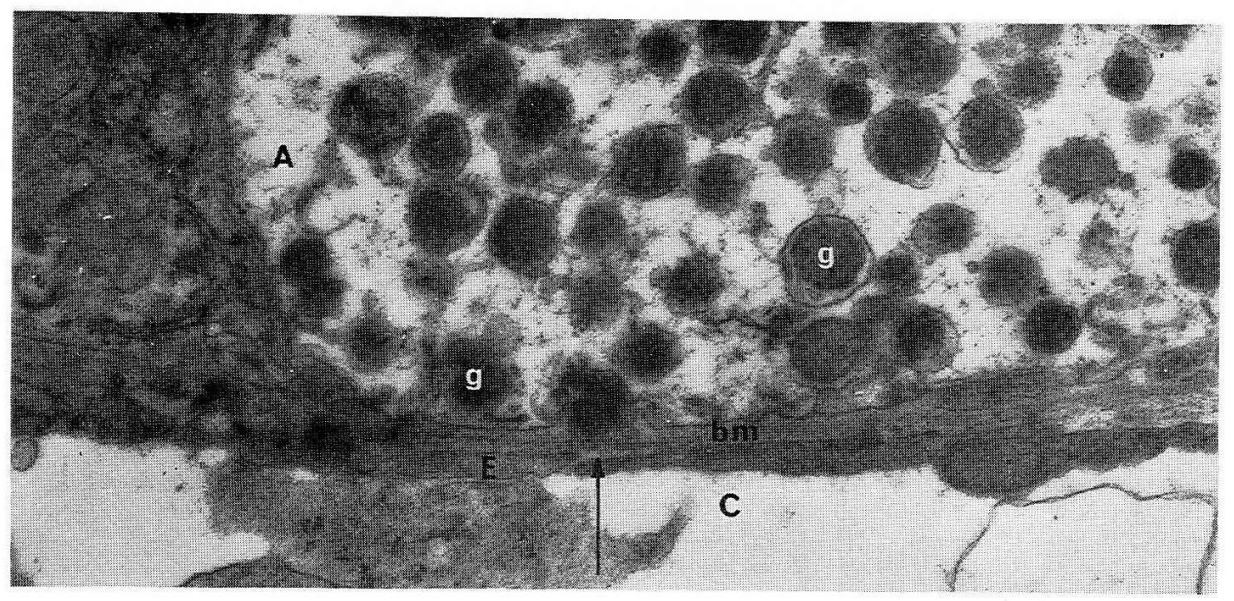

Fig. 3. A portion of the A cell facing a blood capillary $(C)$. Arrow indicates the emiocytotic release of secretory granules $(g)$. The granular content lies in a perivascular space between the plasma membrane and capillary endothelium $(E)$. bm basement membrane. $\times 20,000$

As generally expected, cellular organelles were not so developed in the heavily granulated A cell as in those devoid of granules. The Golgi complex was often observed near the nucleus, and consisted of lamellae, vacuoles, and vesicles. Some of these vesicles rarely contained a small amount of moderately dense amorphous material, suggesting the formation of A granules (Fig. 2, arrow).

A granules found near the Golgi complex were smaller in size and had a more regular edge and more compact and denser matrix than those in the peripheral area of the cytoplasm (Fig. 2). They seemed to be less mature than the latter. They 


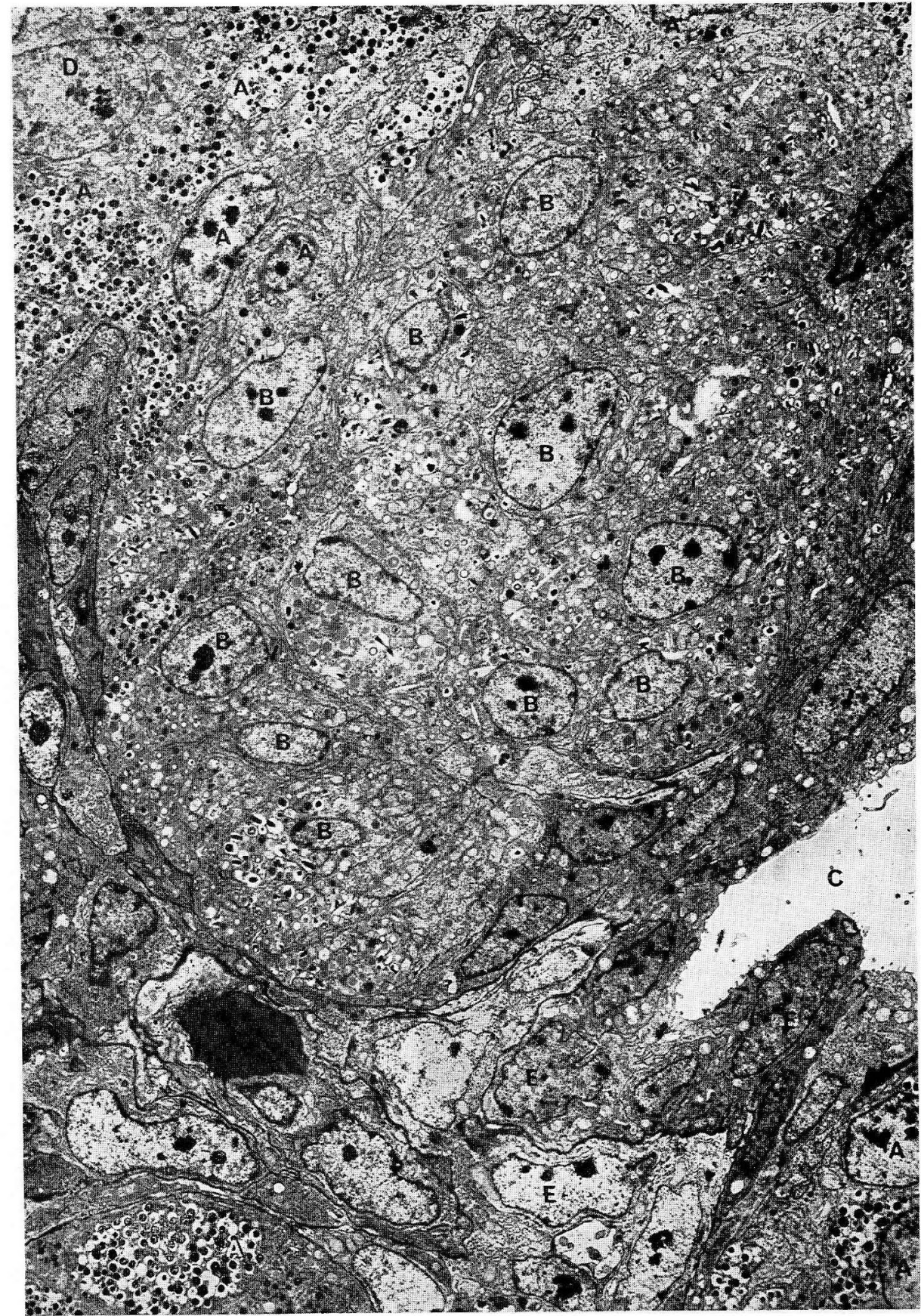

Fig. 4. An electron micrograph of the B islet. Note some A cells $(A)$ in the B islet, which is composed of $\mathrm{B}(B)$ and $\mathrm{D}$ cells $(D)$. The A cells are situated mainly in the periphery and along the capillary $(C)$ of the B islet. $E$ endothelium. $\times 2,500$. 
were almost the same in size, shape and density as granules of the two other cell types (Fig. 2, 6, 8). The maturation process, however, might probably be characteristic of each cell type. It seems no doubt that in its maturation process the A granule increases in size with a serrated edge and forms an inner glomerular structure in the cytoplasm, especially in its peripheral zone (Fig. 2).

The limiting membrane of the granule often came into fusion with the plasma membrane. A pore opened in the fused part through which the content of the granule was often extruded from the cell without undergoing any deformation (Fig. 3). Thus, the present investigation was believed to have revealed the mechanism of release of A cell granules which is to be called emiocytosis. This sequence was observed more frequently in A cells than in B or D cells and more granules were released into the perivascular space than into the intercellular space, although they could pass through every part of the cytoplasmic membrane into the extracellular space.

The $\mathrm{B}$ islets were always smaller than the A islets. They were distributed widely all over the pancreas. In general, they were composed of many B cells and a few $\mathrm{D}$ cells. B islets found in the tail of the pancreas also contained clumps of A cells which were situated principally in the periphery of each islet and which adjoined to the capillary in many cases (Fig. 4). A cells in the B islet were not so many as B cells in the A islet. It seems, however, the B islet may also belong to the "mixed type," in which all three cell types mingle with one another.

The B cells were oval or polygonal and were characterized by the presence of peculiar granules which were extremely variable in shape and density, even within the same cell, and which were certain to be enclosed by a smooth membrane (Fig. 6). The granules were $580 \mathrm{~m} \mu$ on the average (ranging from 350 to $960 \mathrm{~m} \mu$ ) in diameter and usually larger than those contained in the A cells. Some of them were filled with a less dense amorphous material which was enclosed by a limiting membrane (Fig. $6, g_{1}$ ). A few granules were composed of a less dense, ring-shaped amorphous matrix with a spherical halo zone at the center (Fig. $6, \mathrm{~g}_{2}$ ), which often had a dense core (Fig. 6, $g_{3}$ ). A few granules showed the same inner glomerular structure as A granules (Fig. 7c). Most of the remaining granules appeared as needle-like, barshaped crystals or overlapping rods arranged in several directions. Most of those crystals were within a prominent lucent space and enclosed with a limiting membrane (Fig. 6, 7a, b, c, d). Each cell contained these various types of granules simultaneously (Fig. 6) or only a single one of the granules. The proportion of each type of granules seems to alter according to the functional stage of the cell.

The nucleus was small and round in B cells. Various types of inclusion bodies were often demonstrated in it (Fig. 5a, b). Rough endoplasmic reticulum developed in B cells containing inclusion bodies in the nucleus, though these cells were devoid of granules. Heavily granulated B cells, especially those with crystalloid granules, contained only a few organelles. On the contrary, degranulated B cells containing only a few granules had relatively well developed organelles.

The Golgi complex developed generally in the paranuclear region of the B cell, regardless of the presence or absence of granules. It consisted of lamellae, vacuoles and vesicles. A few of these vesicles sometimes contained a small amount of moderately dense amorphous material, which may be a precursor of granules (Fig. 6, arrow). In the B cells, the course of condensation of secretory substance was hardly exhibited 

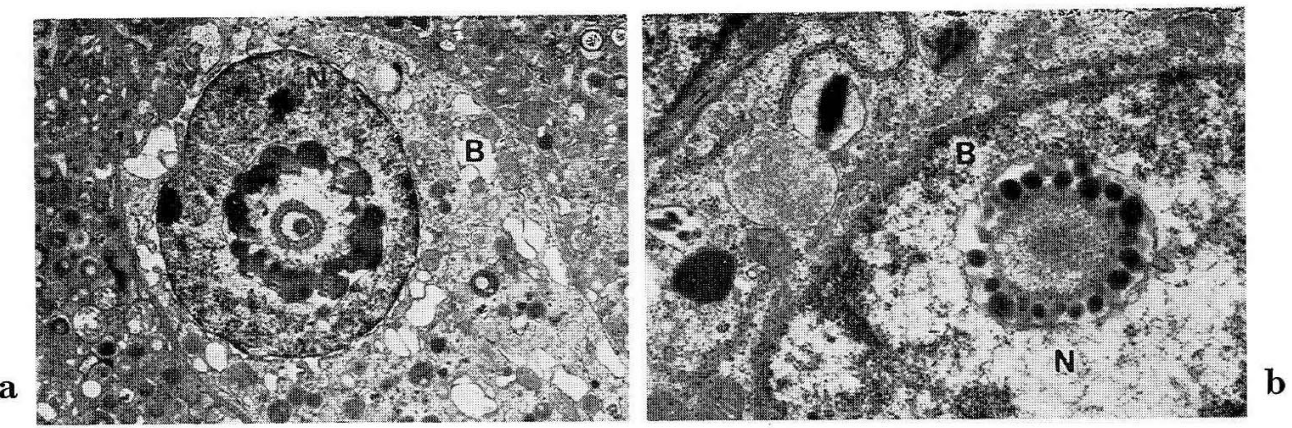

Fig. 5. a. and b. Inclusion bodies in the nuclei $(N)$ of the B cell $(B)$. They occur more frequently in the B cell than in the A cell. a : $\times 4,400$. b : $\times 14,000$.

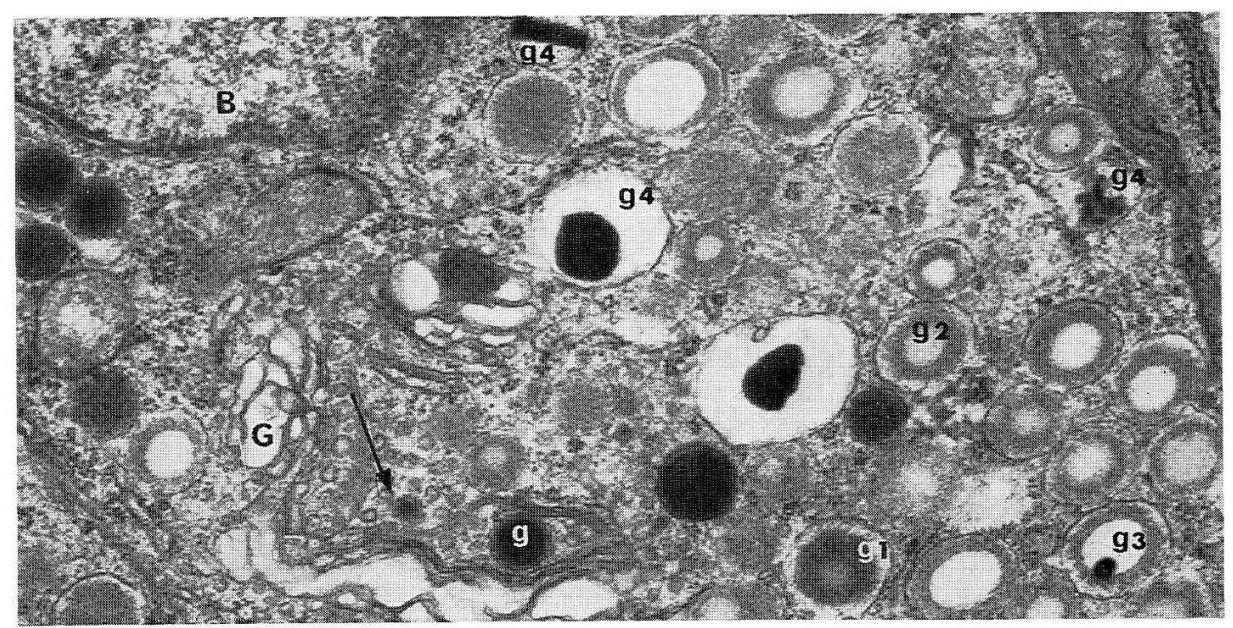

Fig. 6. Golgi complex $(G)$ of the B cell $(B)$. The appearance of a moderately dense substance in a small Golgi vesicle suggests the granule formation (arrow). Immature granules ( $g$ ) within the Golgi area show almost the same appearance as those of A and D cells. Compare with Figures 2 and 8. Polymorphic granules with a numeral order represent the stages of maturation process of B granules. $\times 20,000$.

in the Golgi complex. It could occasionally be observed that the immature secretory substance was condensed into secretory granules within the Golgi complex. B granules found near the Golgi complex were spherical in shape, and had a more compact and denser matrix than those found in the periphery. They seemed to be less mature than those contained in the cytoplasm and belonging to such various types mentioned above. They were almost the same in size, shape and density as those contained in the other two cell types (Fig. 2, 6, 8).

It has been mentioned that many types of granules occurring in B cells may probably represent many stages of the maturation process. Therefore, the authors would like to propose the following course of condensation of the substance secreted from the Golgi complex to the periphery of the cytoplasm: Compact and dense immature 

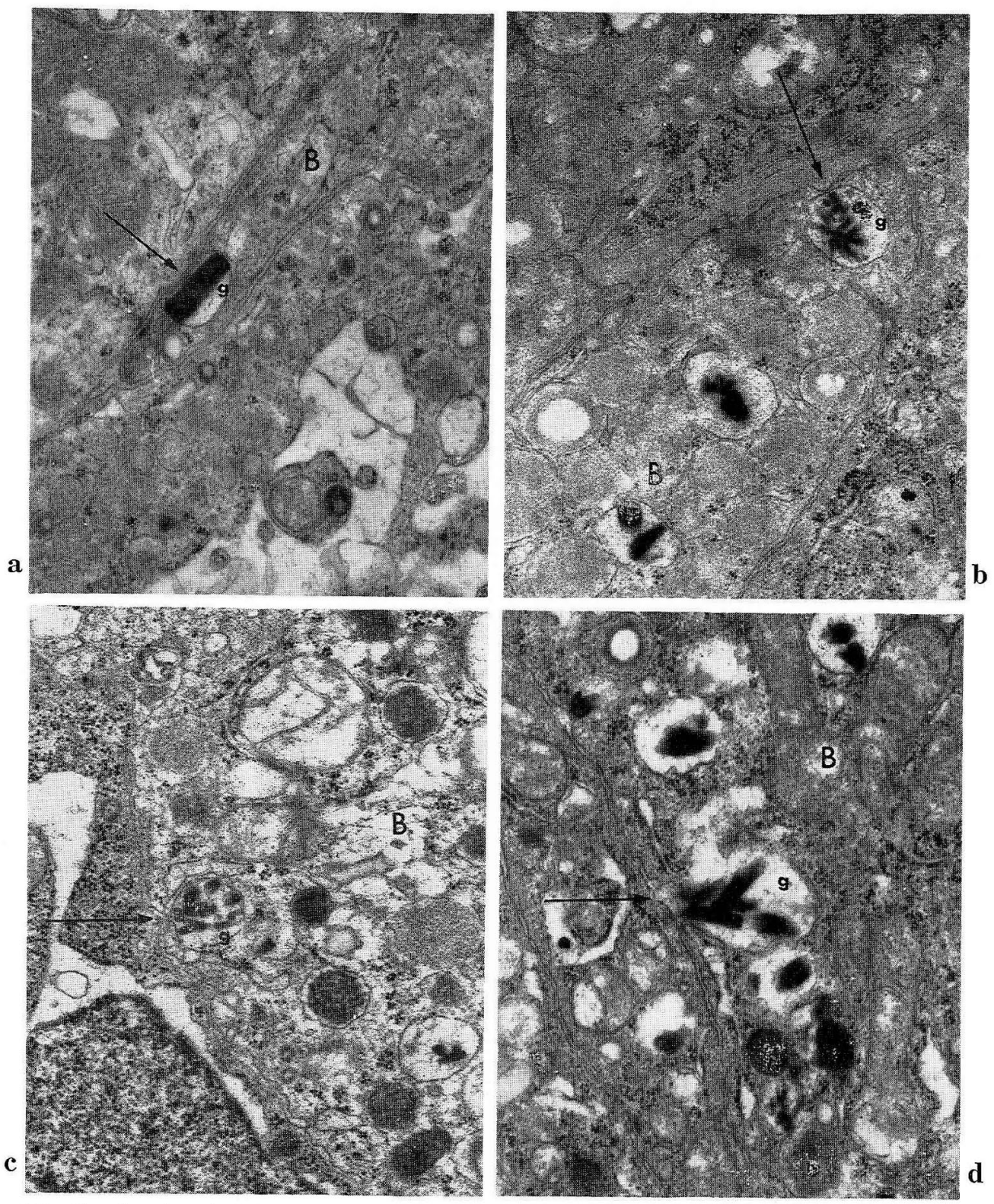

Fig. 7. A series of electron micrographs showing the release of crystalloid B granules (arrows). $\times 20,000$. a. The limiting membrane of the secretory granule being in touch with the plasma membrane. b. The plasma membrane has become hollow to get in contact with the limiting membrane of the secretory granule from outside. c. Both membranes have formed a pore to release the contents into the pericellular space. d. Through the enlarged pore, a crystalloid granule is going to be released into the intercellular space. 
granules within the Golgi complex increase in diameter at first and then exhibit an inner glomerular structure and irregular edges. Their contents change into a less dense amorphous matrix by a gradual decrease in density (Fig. 6, $g_{1}$ ). The amorphous matrix begins to disappear from the center of each granule (Fig. 6, g2), at which a lucent space appears. In the next stage crystals of high density appear in the lucent space at the center of the granule $\left(\mathrm{Fig} .6, \mathrm{~g}_{3}\right)$. They increase in volume, but the peripheral ring-shaped amorphous matrix disappears (Fig. 6, $\mathrm{g}_{4}$ ). Thus, typical crystalloid granules are formed in the B cell. The limiting membrane seems to undergo no changes during this process.

A series of electron micrographs indicated different stages of granule release in the B cell (Fig. 7). The limiting membrane of the granule was in touch with the plasma membrane (Fig. 7a), which often became hollow to get in contact with the limiting membrane of the granule from outside (Fig. 7b). Then a pore opened at the fused site (Fig. 7c). This pore seemed to enlarge enough to release crystals (Fig. 7d). Therefore, from these findings it is proposed that the mechanism of granule release in the B cell should be called emiocytosis.

The third cell type was the D cell which was contained both in A and B islets. The cells of this type were generally situated along capillaries throughout both islets. They were roughly spherical or polygonal in shape and contained a variable number of spherical granules, which were variable in density, but always less dense than A granules. Those granules were $470 \mathrm{~m} \mu$ (ranging from 280 to $700 \mathrm{~m} \mu$ ) in diameter and surrounded by a limiting membrane which often was partially indistinct. The nucleus was ovoid or polygonal and often showed indentation. Such organelles as are generally accepted were observed. They were not so well developed in D cells fully granulated as in those devoid of granules. This was a common phenomenon in $\mathrm{A}$ and $\mathrm{B}$ cells.

The Golgi complex was often present in the paranuclear region and consisted of

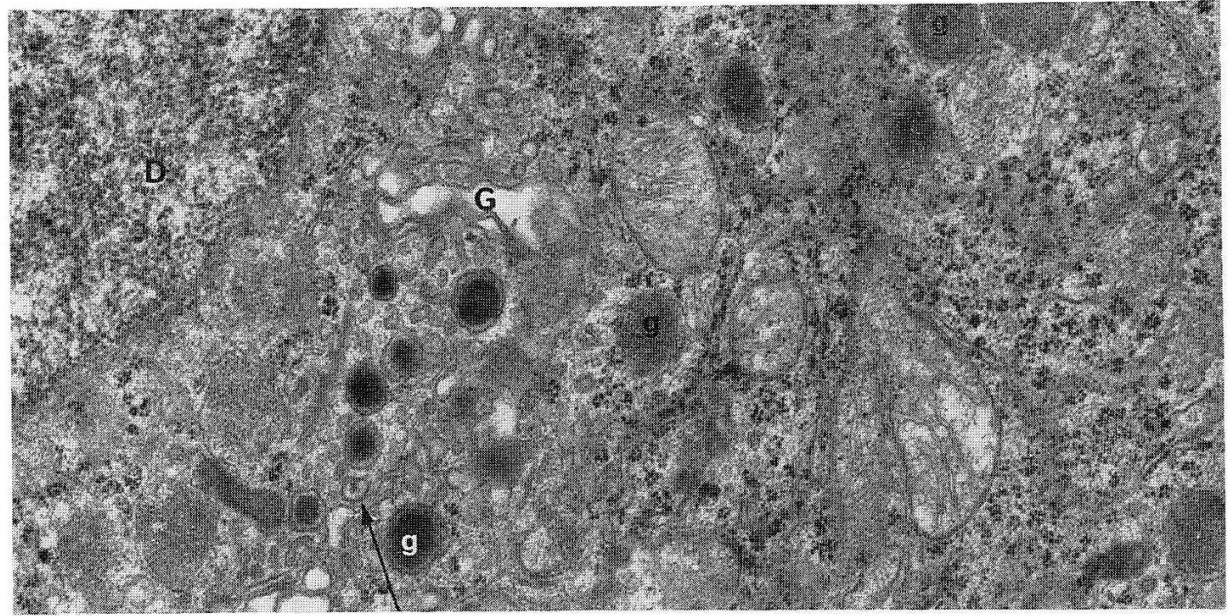

Fig. 8. Golgi complex $(G)$ of the D cell $(D)$. The presence of a small amount of amorphous material in a small Golgi vesicle suggests the formation of D granule (arrow). Immature granules $(g)$ within the Golgi area have almost the same appearance as those of A and B cells. Compare with Figures 2 and $6 . \quad \times 20,000$ 
lamellae, vacuoles and vesicles. A few of these vesicles contained a small amount of moderately dense amorphous material, suggesting the formation of D granules (Fig. 8, arrow). The matrix of D granules within the Golgi complex was compact and separated from the limiting membrane by a narrow, vaguely light zone. These granules were smaller in size and much higher in density than those found in the periphery (Fig. 8). They seemed to be less mature than those found in the periphery which were low in density. They were almost the same in size, shape and density as those contained in the two cell types (Fig. 2, 6,8). Granules of the intermediate form were located around the Golgi complex.

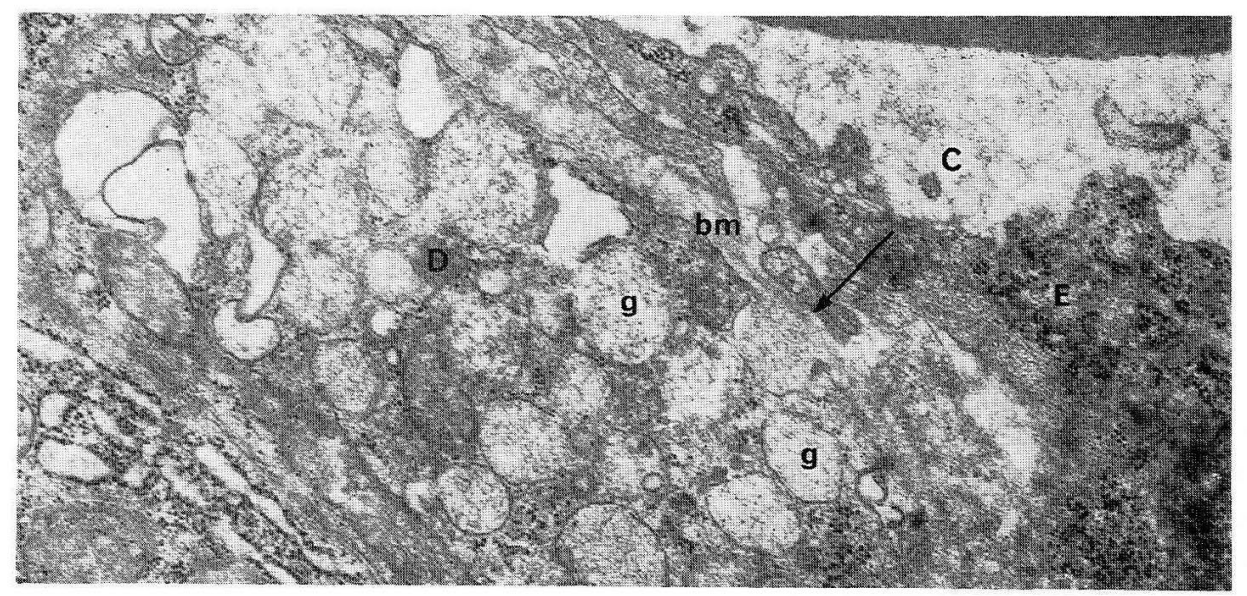

Fig. 9. A portion of the $\mathrm{D}$ cell $(D)$ facing a blood capillary $(C)$. It shows the emiocytotic release of secretory granules which are scattered around the perivascular space (arrow). $b m$ Basement membrane, $E$ endothelum. $\times 20,000$

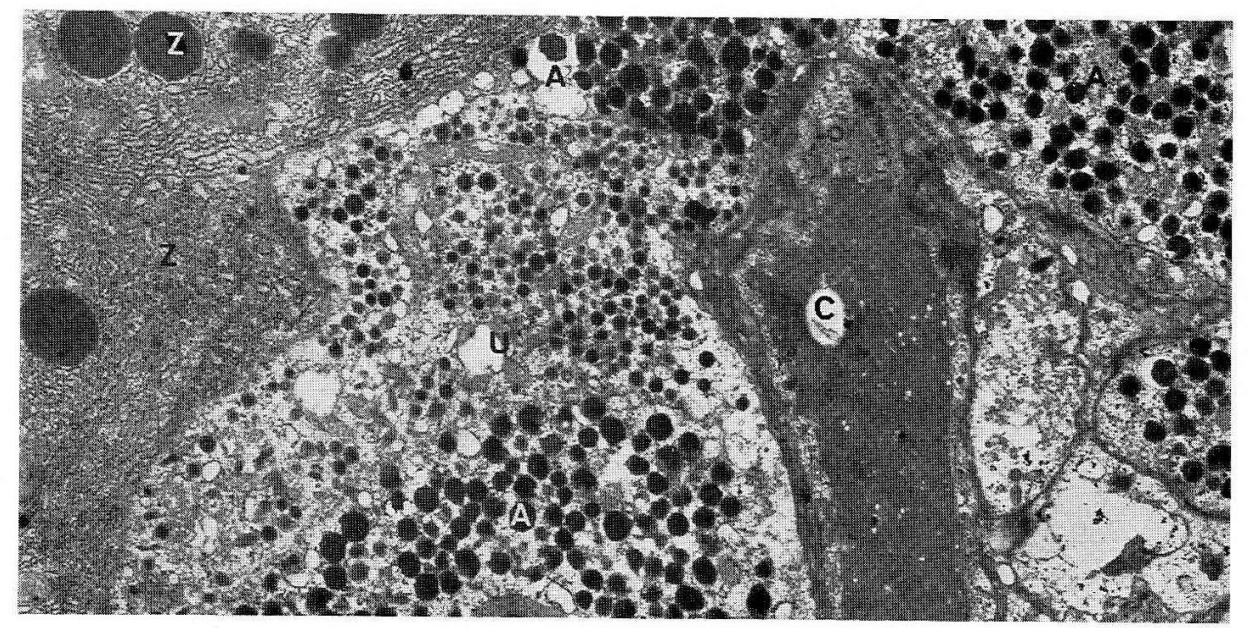

Fig 10. A portion of the unusual cell $(U)$ facing a blood capillary $(C)$ between the exocrine $(Z)$ and the endocrine tissues, $\mathrm{A}$ islet $(A)$. It contains a number of the smallest granules of the secretory granules in the pancreas. The granules are nearly spherical in shape and are variable in diameter and density. $\times 6,000$ 
It seems no doubt that in their maturation process, D cell granules may increase in size and decrease in density (Fig. 8). In these granules, the limiting membrane came into fusion with the plasma membrane and a pore was formed at the site of fusion. Then the pore enlarged and the granular content communicated with the extracellular space by way of typical "omega figures." The content of D cell granules of low density seemed to be discharged through the pore (Fig. 9, arrow). From these findings, it is proposed that the mechanism of release of D cell granules should be called emiocytosis.

A small number of cells which did not belong to the three islet cell types (A, B and $\mathrm{D}$ ) were found both in the endocrine and exocrine tissue. These cells were polygonal in shape, and often had elongated processes, and were smaller in size than those of the other cell types. They were characterized by the presence of spherical or rod granules with the limiting membrane in the cytoplasm. The granules which appeared quite variable in density were $240 \mathrm{~m} \mu$ on the average (ranging from 170 to $430 \mathrm{~m} \mu$ ) in diameter and usually were half the diameter of A granules. Their appearance differed from those of either the A or D cell. Little is known about this unusual cell.

\section{Discussion}

It is well known that two types, "dark" and "light," islets are noted in the avian pancreas by light microscopy.

The cell types of the avian pancreatic islets have been examined electron microscopically by the following investigators. BJörkman and Hellman (1964) observed in the duck that the dark islet was composed of two types of A cells, one of which, $\mathrm{A}_{1}$ cells were located predominantly around capillaries, and that the light islet was composed of many $B$ cells and a few $A_{1}$ cells found in the periphery of the islet. BRAUN-BLANQUET (1969) noted in the duck that the dark islet was composed of many A cells and a few D cells, and that the clear islet was composed of B cells surrounded by a mantle of A cells. Quoting the investigations of EPPLE (1964) and RoTH (1968), KoBAYASHI and FujITA (1969) pointed out in the pigeon that there frequently occurred islets of a mixed type which contained all three cell types mingled with one another. Peter (1970) indicated in the chick embryo that the dark island consisted almost completely of A cells, which contained granules of both high and low density, and that the light island contained B cells surrounded by a mantle of A cells. Mikami and Mutoн (1971) performed a detailed study on the distribution pattern of cell types in the chick pancreatic islets. They reported that the A islet consisted of many $A$ cells and a few D cells and occasionally contained a few B cells, and that the B islet contained many B cells and a few D cells, and no A cells. The findings reported by Smith (1974) in the quail seem to lend support to the results obtained by MikAmI and Мuтон (1971), although they indicated the presence of a few B cells in the A islet.

The present study provides electron micrographs of both A and B islets containing all three cell types. These results obtained from the A islet seem to agree with the findings reported by Björkman and Hellman (1964), Braun-Blanquet (1969), Kobay ashi and Fujita (1969), and Mikami and Mutoh (1971), and those from the B islet with the findings by BRAUN-Blanquet (1969) and Peter (1970), although the latter 
indicated no D cells in the B islet.

Svennevig (1967) examined the duck pancreas by the light microscope to find that light islets were produced from the dark islets by the typical budding of the B cell group on the day of hatching. This result was supported by the electron microscopical findings of Peter (1970) in the chicken. There seems to be significant evidence for the independence of $A$ islets from $B$ islets of the avian pancreas only in phylogeny.

According to the previous authors (Machino et al., 1966a; Sato et al., 1966; Przybylski, 1967; Machino and Sakuma, 1968; Mikami and Mutoh, 1971), A granules are distinctly spherical, highly dense and separated from the limiting membrane by a narrow halo zone, and often show an inner glomerular structure. The A granules are about $400 \mathrm{~m} \mu$ on the average in diameter. These results coincide with those of the present observation.

It is generally known that the $\mathrm{B}$ granules are characteristic polymorphic, needleor bar-shaped, crystals of high density located within a membrane-enclosed space, giving the appearance of an obvious halo. The proportion of polymorphic granules in B cells varies from cell to cell. This morphological variation is presumed to show the stages of maturation process described by PRZYBYLsKI (1967). It should be noted that the present study is the first to propose the process of condensation or maturation of B granules.

As for D cells in the chicken pancreas, previous authors (MAcHino et al., 1966b; Machino and Sakuma, 1968; Mikami and Mutoh, 1971) pointed out that D cells were characterized by the presence of round granules of low density mostly $500 \mathrm{~m} \mu$ in diameter enclosed clearly in a limiting membrane. The present study found the structure of $\mathrm{D}$ cells to be identical with that described by the authors mentioned above.

Utilizing the immunofluorescent antibody technique in some mammalian species, there were two opposite reports that D cells included the gastrin (LoMSKy et al., 1969), but that the gastrin was not demonstrated in the cells of isolated islet (DorN et al., 1974). On the other hand a pancreatic polypeptide (APP) containing 36 amino acid residue had been isolated from the avian pancreas (KImmel et al., 1971). It was suggested that APP represented another pancreatic hormone by a radioimmunoassay (LANGSLow et al., 1973), and exerted a "gastrin like" secretogogic action on the proventriculus (HAZELWOod et al., 1973).

LARsson et al. (1974) postulated by immunofluorescence microscopy that APP cells had the appearance of polypeptide hormone-producing cells, and that their granules showed some resemblance but were not identical to that of the D cell.

SMITH (1974) reported on Japanese quail by electron microscopy that Type IV cell was found mainly in the A islets and contained granules of differing densities, but they differed from those of the D cell. The question whether or not the unusual cells which were found in the fowl pancreas by the authors might correspond to the type IV cell of Smith (1974) remains unknown.

Howell et al. $(1969,1970)$ reported by electron microscopic radioautography that the labeled amino acid was incorporated initially in the rough endoplasmic reticulum, and that the label subsequently appeared in the islet granules, and the Golgi complex participated either in the formation of the islet granules or in the translocation of the granules through the cytoplasm of the cell.

Some biochemical studies of glucagon biosynthesis in islets from the duck (KRUG 
and Mialhe, 1970; Krug et al., 1971) and the pigeon (Tung and ZeregA, 1971; Tung, $1973,1974)$ showed a rapid incorporation of the labeled amino acid into proglucagon with little incorporation into glucagon. These results suggested that a proglucagon might represent minor biosynthetic forms. The study of insulin biosynthesis in the bovine fetal pancreatic slices (TUNG and YIP, 1969) indicated the hypothesis that insulin was synthetized as a single-chain polypeptide on the ribosomes, and that intracellular proteolysis in the subcellular membranous organelles and B granules converted the single-chain proinsulin to insulin by means of a double-chain intermediate.

The authors could only observe the accumulation of a dense substance in the small Golgi vesicles. This change may show the occurrence of newly formed granules within the Golgi complex in the A, B and D cells. The secretory granules were clearly varied among the three cell types, but the newly formed granules were almost the same in size, shape and density among these types. These results surely indicated that there was a marked difference in the maturation process of secretory granules among the three cell types, as suggested by Björkman and Hellman (1964).

From the in vitro studies mentioned above, it may be postulated that the proteinic secretory substances synthesized on the ribosomes and converted into such high molecular weight proteins as proglucagon and proinsulin may be contained in the small Golgi vesicles, which show almost the same morphological characters among three cell types as revealed in the present study. Concentration and conversion of these substances to completed hormones like glucagon and insulin and incorporation of other granule constituents like lipids and sugars appears to be accompanied by significant changes in the morphology of the granules during their translocation and maturation. Especially marked is the change in B cell granules in which insulin seems to be crystallized with the aid of zinc. The biochemical study of WeIzeL et al. (1956) in the islet of the duck suggests that the zinc plays an important role also in the formation of glucagon in A cell granules.

Postulates have been presented by many investigators on the extrusion mechanism of secretory granules. Concerning A cells, it is highly probable that A granules may be released mainly by emiocytosis, as reported by MAchino (1966), MAchino et al. (1966a), and Mikami and Мutoh (1971). The present study also revealed the emiocytotic release of secretory granules in A cells.

As for B cells of the avian pancreas, some investigators (PRZYBYLSKI, 1967; MIKAMI and МutoH, 1971) proposed emiocytotic extrusion, but no one has actually observed emiocytosis in any B cell of the avian pancreas. Recently, BENZo and GreEN (1974) recognized the emiocytotic extrusion in B cells of the chick embryo, lending support to the results of the present observation.

KIMmEL et al. (1968) reported from their physiological study that the insulin content of the fowl pancreas was as low as $1 / 7$ to $1 / 10$ that of the mammalian pancreas. On the contrary, the fowl pancreas and plasma contained about ten times as much glucagon as the mammalian (Vuylsteke and DE Duve, 1953; Hayashi and Saeki, 1974). It should be noted that the findings mentioned above may probably be related to the independence of $\mathrm{A}$ islets from B islets, the lots of emiocytotic release of A granules in the avian pancreas and the rich sympathetic nerve supply to this organ.

Some investigators (Fujit A and Matsuno, 1967; WATARI et al., 1970) postulated that the second type of B granule release might be diacrinous secretion. Mikami and 
Mutoн (1971) reported that the B granule release might occur very rapidly or only during a limited period of time in the chick. The present observation, however, indicated that B granules were released by emiocytosis. Taking this fact and the conception of KIMMEL et al. (1968) into consideration, the possibility of diacrine secretion of granules by B cells in the domestic fowl does not seem tenable any more.

As for D cells, the present study provides electron micrographs indicating the process of emiocytotic release of D granules in domestic fowl. This process corresponds to that demonstrated by Machino et al. (1966b) in domestic fowl and by KoBAYASHI and FuJITA (1969) in the pigeon.

\section{ニワトリ脺島の微細構造一とくに細胞型と分泌について}

渡辺徹, 白泳基, 保田幹男

ニワトリの脺島を電子顕微鏡で観察し，次の結果を得た.

1. A島は多数のA細胞と 少数の D 細胞からなるが, その他に毛細血管に沿って 少数 のB細胞もみられる。

2. 一方 $\mathrm{B}$ 島は多数の $\mathrm{B}$ 細胞と, 少数の $\mathrm{D}$ 細胞からなるが, $\mathrm{B}$ 島の周縁に少数の $\mathrm{A}$ 細胞 が点在し，両島とも三種の島細胞の混合型である.

3. 三種の島細胞のゴルジ装置の中に，未熟な分泌果粒がみられるが，とれらの大きさ， 型，電子密度はほぼ同じである。しかし，胞体でみられる分泌果粒は，三種の島細胞で相 互に全く異なるから，分泌果粒の成熟過程の様式が相互に異なると思われる.

4. 三種の島細胞の分泌果粒は, 全て emiocytosis と名付けられる放出様式により分泌 される.

\section{References}

Benzo, C. A. and T. D. Green : Functional differentiation of the chick endocrine pancreas: Insulin storage and secretion. Anat. Rec. 180: 491-496 (1974).

Björkman, N. and B. Hellman: Ultrastructure of the islets of Langerhans in the duck. Acta anat. 56: 348-367 (1964).

Braun-Blanquet, M. : Examen du pancréas de canard normal au microscope électronique précédé de son observation macroscopique et microscopique. I. Glande exocrine. Acta. anat. 72: 161194 (1969).

Dorn, A., D. Lorenz, H.-J. Hahn, G. Koch und M. Ziegler : Untersuchungen zum immunohistochemischen Nachweis von Insulin, Glucagon und Gastrin in isolierten Langerhansschen Inseln von Ratte und Maus. Acta histochem. 49: 153-157 (1974).

Epple, A.: Weitere Untersuchungen über ein drittes Pankreashormon. Verh. Deut. Zool. Ges. 1965, Ergänz. z. Zool. Anz. 29: 459-470 (1966).

Fujita, H. and Z. Matsuno: Some observations on the fine structure of the pancreatic islet of rabbits, with special reference to $B$ cell alteration in the hypoglycemic state induced by alloxan treatment. Arch. histol. jap. 28: 383-398 (1967). 
Hayashi, M. and T. Saeki : Studies on hormonal regulation of carbohydrate metabolism in chicken. V. Radioimmunoassay of chick plasma glucagon. Jap. J. vet. Sci., Suppl. for the 78th Meeting, p. 45 (1974).

Hazelwood, R. L., S. D. Turner, J. R. Kimmel and H. G. Pollock: Spectrum effects of a new polypeptide (third hormone?) isolated from the chicken pancreas. Gen. comp. Endocrinol. 21: 485-497 (1973).

Howell, S. L. , C. Hellerström and M. Whitfield : Radioautographic localization of labeled proteins after incubation of guinea-pig islets of Langerhans with $\left[{ }^{3} \mathrm{H}\right]$ tryptophan. Biochem. J. 140: 22-23 (1974).

Howell, S. L., M. Kostianovsky and P. E. Lacy : Beta granule formation in isolated islets of Langerhans. A study by electron microscopic radioautography. J. Cell Biol. 42: 695-705 (1969).

Karnovsky, M. J.: A formaldehyde-glutaraldehyde fixative of high osmolality for use in electorn microscopy. J. Cell Biol. 27: 137A (1965).

Kimmel, J. R., H. G. Pollock and R. L. Hazelwood : Isolation and characterization of chicken insulin. Endocrinology 83: 1323-1330 (1968).

—- - A new pancreatic polypeptide hormone. Fed. Proc. 30: 1318, abst. 1550 (1971).

Kobayashi, S. and T. Fujita : Fine structure of mammalian and avian pancreatic islets with special reference to D cells and nervous elements. Z. Zellforsch. 100: 340-363 (1969).

Krug, E., O. Biehler and P. Mialhe: Molecular weight of gut and pancreas circulating glucagon in the duck. Hormone Metab. Res. 3: 258-261 (1971).

Krug, E. and P. Mialhe: Pancreatic and intestinal glucagon in the duck. Hormone Metab. Res. 3: 24-27 (1970).

Langslow, D. R., J. R. Kimmel and H. G. Pollock: Studies of the distribution of a new avian pancreatic polypeptide and insulin among birds, reptiles, amphibians and mammals. Endocrinology 93: 558-565 (1973).

Larsson, L.-I., F. Sundler, R. Håkanson, H. G. Pollock and J. R. Kimmel : Localization of APP, a postulated new hormone, to a pancreatic endocrine cell type. Histochemistry 42: 377382 (1974).

Lomsky, R., F. Langer and V. Vortel: Immunohistochemical demonstration of gastrin in mammalian islets of Langerhans. Nature (Lond.) 233: 618-619 (1969).

Luft, J. H.: Improvements in epoxy resin embedding methods. J. biophys. biochem, Cytol. 9: 409-414 (1961).

Machino, M.: Electron microscopic observations of pancreatic islet cells of the early chick embryo. Nature (Lond.) 210: 853-854 (1966).

- On the substructures of secretory granules of the chick beta islets cell. J. Ultrastr. Res. 31: 199-201 (1970).

Machino, M., T. Onoe and H. Sakuma : Electron microscopic observations on the islet alpha cells of the domestic fowl pancreas. J. Electron Microsc. (Tokyo) 15: 249-256 (1966).

Machino, M. and H. Sakuma : The secretory activity of the pancreatic delta cells of the young chick and the chick embryo. J. Endocrinol. 40: 129-130 (1968).

Machino, M., H. Sakuma and T. Onoe: The fine structure of the D-cells of the pancreatic islets in the domestic fowl and their morphological evidence of secretion. Arch. histol. jap. 27: 407-418 (1966).

Mikami, S. and K. Mutoh : Light- and electron-microscopic studies of the pancreatic islet cells in the chicken under normal and experimental conditions. Z. Zellforsch. 116: 205-227 (1971).

Millonig, G.: Further observations on a phosphate buffer for osmium solutions in fixation. In: Electron microscopy (Proc. 5th Int. Congr. Electron Microscopy). New York, Academic Press, 1962. (Vol. 2, p. 8). 
Peter, S.: Die Feinstruktur des Inselorgans im Pankreas des Huhnes in den ersten Lebenstagen und Wochen. Arch. mikrosk.-anat. Forsch. 81: 387-404 (1970).

Przybylski, R. J.: Cytodifferentiation on the chick pancreas. I. Ultrastructure of the islet cells and the initiation of granule formation. Gen. comp. Endocrinol. 8: 115-128 (1967).

Roth, A.: Quantitative studies on the islets of Langerhans in the pigeon. Acta anat. 69: 609-622 (1968).

Sabatini, D. D., K. Bensch and R. J. Barrnett : Cytochemistry and electron microscopy. The preservation of cellular ultrastructure and enzymatic activity by aldehyde fixation. J. Cell Biol. 17: 19-58 (1963).

Sato, T., L. Herman and P. J. Fitzgerald: The comparative ultrastructure of the pancreatic islet of Langerhans. Gen. comp. Endocrinol. 7: 132-157 (1966).

Smith, P. H. : Pancreatic islets of the Coturnix quail. A light and electron microscopic study with special reference to the islet organ of the splenic lobe. Anat. Rec. 178: 567-586 (1974).

Svennevig, J.-L.: Entwicklung des Inselorgans bei der Hausente, die Entstehung der dunklen und der hellen Inseln. Z. mikrosk.-anat. Forsch. 76: 568-584 (1967).

Tung, A. K.: Biosynthesis of avian glucagon: Evidence for a possible high molecular weight biosynthetic intermediate. Hormone Metab. Res. 5: 416-424 (1973). : Glucagon biosynthesis in avian pancreatic islets: Evidence for medium-sized biosynthetic intermediates. Can. J. Biochem. 52: 1081-1086 (1.974).

Tung, A. K. and C. C. Yip : Biosynthesis of insulin in bovine fetal pancreatic slices: The incorporation of tritiated leucine into a single-chain proinsulin, a double-chain intermediate, and insulin in subcellular fractions. Proc. Nat. Acad. Sci. 57: 442-449 (1969).

Tung, A. K. and F. Zerega: Biosynthesis of glucagon in isolated pigeon islets. Biochem. Biophys. Res. Comm. 45: 387-395 (1971).

Vuylsteke, C. A. et C. de Duve : Le contenu en glucagon du pancréas aviaire. Arch. int. Physiol. 61: 273-274 (1953).

Watari, N., N. Tsukagoshi and Y. Honma: The correlative light and electron microscopy of the islets of Langerhans in some lower vertebrates. Arch. histol. jap. 31: 371-392 (1970).

Weitzel, G., E. Buddecke und D. Kraft: Zink und Glucagon im Pankreas der Ente. HoppeSeylers Z. physiol. Chem. 305: 132-142 (1956).

\author{
渡辺徹 \\ T464 名古屋市千種区不老町 \\ 名古屋大学農学部 \\ 家畜解剖学教室
}

Dr. Tohru Watanabe

Department of Veterinary Anatomy

Nagoya University Faculty of Agriculture

Furo-cho,Chigusa-ku

Nagoya, 464 Japan 